\title{
Impact of $100 \%$ organic diets on pig performance, carcass composition and carcass nutrient deposition efficiency
}

\author{
Giuseppe Bee (D) - Silvia Ampuero Kragten • \\ Barbara Früh • Marion Girard
}

Received: 2 September 2020 / Accepted: 13 January 2021 / Published online: 9 February 2021

(C) The Author(s) 2021

\begin{abstract}
The ultimate objective of organic pig production is to use ingredients of $100 \%$ organic origin in the animals' diets. However, this approach is challenging, especially when needing to ensure adequate quantities of essential amino acids (EAAs) and protein in growerfinisher diets. The current standard is $95 \%$ organic feed ingredients, but this percentage can be increased by reducing the EAA supply or by accepting an unbalanced EAA profile. A further incentive also exists to include forages in organic diets as a way to raise dietary crude fibre content. The current study therefore investigates three organic diets (T95: 5\% of non-organic origin; T100: $0 \%$ of non-organic origin and T100-CF: T100 plus an increased crude fibre level), which were offered ad libitum to 48 pigs (16 per diet) weighing 22 to 110 $\mathrm{kg}$. Comparison of the three diets revealed that increasing the crude fibre content (T100-CF) reduced growth, increased total feed intake and impaired feed and protein deposition efficiency, but the unbalanced EAA profile (T100) had no effect on growth traits and protein deposition efficiency. The T100 and T100-CF pigs differed from the T95 pigs in terms of feeding behaviour traits, as they displayed more frequent but shorter feeder visits, shorter between-meal intervals and smaller meals. Increasing the fibre content with press cake ingredients
\end{abstract}

G. Bee $(\bowtie) \cdot$ S. A. Kragten $\cdot$ M. Girard

Agroscope, 1725 Posieux, Switzerland

e-mail: giuseppe.bee@agroscope.admin.ch

B. Früh

Research Institute of Organic Agriculture (FiBL), Ackerstrasse 113, 5070 Frick, Switzerland raised the degree of unsaturation of the backfat and might cause problems in meat processing. In conclusion, the results revealed that pigs could cope with a mild EAA imbalance.

Keywords Organic feeding $\cdot$ Feeding behaviour $\cdot$ Dualenergy X-ray absorptiometry (DEXA) · Fatty acid composition · Backfat

\section{Introduction}

In 1999, the Council Regulation (EC) No 1804/1999 defined a detailed listing of approved feedstuffs for organic livestock production, while also recognising that organic pig producers might encounter difficulties in obtaining the necessary quantities of these organically produced feedstuffs. Since 30 May 2018, the Council Regulation (EC) No 834/2007 has therefore provisionally (until 31 December 2025) allowed that $5 \%$ of the annual dry matter (DM) may originate from nonorganically produced feedstuffs; however, the ultimate goal remains to reach a compulsory $100 \%$ organic feed for these pigs. This envisaged change will amplify the already existing difficulties in feed formulation for organic monogastrics due to the protein gap, defined as the lack of organic protein sources with an adequate amino acid pattern (Zollitsch 2007).

Meeting the nutritional requirements with respect to the essential amino acid (EAA)-to-digestible-energy ratio for today's modern pig breeds is still difficult. As pointed out by Wlcek and Zollitsch (2004), two 
strategies are currently combined to overcome this challenge: (1) the required contents of EAAs are partly covered by an excess amount of protein feeds in the diet and (2) high-quality protein feeds, like potato protein or whey powder, are used as the 5\% non-organic ingredients. The first strategy has a distinct shortcoming from the standpoint of environmental impact and resource efficiency, whereas the second strategy is not compatible with a $100 \%$ organic feed resource perspective as sources like potato protein could no longer be used.

Only limited scientific data are available on the impact of feeding pigs on $100 \%$ organic feed sources. The common conclusions of these studies indicate that the elimination of non-organic high-quality protein sources will impair pig growth (Hansen et al. 2006; Sundrum et al. 2011). The main reason for this impairment is the unbalanced EAA profile of the diets, caused by the inclusion of grain legumes (Bracher 2019) that are commonly used to replace sources like potato protein. Apart from the $100 \%$ organic feed objective, organic pig production also has an incentive to increase the level of enrichment material to stimulate species-specific foraging behaviour, increase satiety, limit chronic stress and improve health (Holinger et al. 2018). Providing forages to elevate the crude fibre content is one possibility that could comply with this requirement.

Apart from the less than optimal EAA profile, the elevated use of grain legumes and press cakes in pig diets can also be problematic with respect to the fatty acid profile. This is especially the case in countries like Switzerland, where the fat quality is an economically relevant trait (Hadorn et al. 2008), and pig producers are penalised at the abattoir for not complying with the requested fat quality (Scheeder and Muller 2014). For this reason, feeding recommendations were established to limit the quantity of total saturated (SFA), monounsaturated (MUFA) and polyunsaturated (PUFA) fatty acids in the diets of growerfinisher pigs (Stoll 2016). However, these feeding recommendations were established based on conventional cereal/soybean-based diets and thus did not take into account the greater levels of forages used in organic diets. The constraints caused by the protein gap, coupled with the elevated PUFA levels caused by the grain legumes and press cakes, have created a demand for solutions that will minimise the impairment in growth performance and nutrient utilisation efficiency, while still delivering an excellent carcass and fat quality.
The objectives of this study were threefold. The first objective was to determine the impact of a slight reduction in dietary EAA level to allow compliance with $100 \%$ organic feeding; the second was to determine the combined effect of a slight reduction in EAA level and an elevated crude fibre content on pigs' performance and carcass composition and the third was to assess the reliability of achieving the Swiss feeding recommendations for backfat quality when using increased levels of grain legumes and forages. These objectives were tested against results obtained in pigs fed a grower-finisher diet formulated according to the current $95 \%$ organic feeding requirements.

\section{Material and methods}

The Swiss Federal Committee for Animal Care and Use approved all the procedures involving animals.

Animals, diets and slaughtering procedures

Forty-eight Swiss Large White female and castrated pigs, originating from 7 litters $(5$ litters $=3$ females and 3 castrates from each; 1 litter $=6$ females and 3 castrates; 1 litter $=3$ females and 6 castrates) and weighing $22.4 \pm$ $1.44 \mathrm{~kg}$ (average \pm standard deviation), were assigned within litters and sex to three experimental treatments (T95, T100 and T100-CF). The T95 treatment was a grower-finisher diet formulated based on the Swiss feeding recommendations for swine (Agroscope 2017) and following the recommendation that $95 \%$ of the feed ingredients must comply with the BIOSUISSE regulation (https://www.bio-suisse.ch/de/richtlinienweisungen.php). The T100 treatment consisted of $100 \%$ feed ingredients that complied with this regulation. The T100-CF treatment consisted of the T100 formulation, but with the crude fibre content increased by including sunflower press cake, sainfoin and lupine (Table 1). The objective was to reach a crude fibre content in the T100-CF diets twice as high as that of the T100 diets. In addition, the fatty acid profiles of all three diets were formulated to comply with the feeding recommendations regarding backfat quality, namely a PUFA index (PUI) $<5.1 \mathrm{~g} / \mathrm{kg}$ feed and an iodine value index (IVI) $<7.8 \mathrm{~g} / \mathrm{kg}$ feed (Stoll 2016).

The pigs were reared in group pens $\left(1 \mathrm{~m}^{2} / \mathrm{pig}\right)$ equipped with automatic feeders and individual pig recognition systems (Schauer Maschinenfabrik GmbH \& Co. KG, Prambachkirchen, Austria). The animals had ad libitum 
Table 1 Ingredients and nutrient composition of the grower and finisher diets

\begin{tabular}{|c|c|c|c|c|c|c|}
\hline \multirow[t]{2}{*}{ Item } & \multicolumn{3}{|c|}{ Grower diet } & \multicolumn{3}{|c|}{ Finisher diet } \\
\hline & T95 & $\mathrm{T} 100$ & $\mathrm{~T} 100-\mathrm{CF}$ & T95 & $\mathrm{T} 100$ & T100-CF \\
\hline Barley & 26.64 & 25.00 & - & 73.01 & 49.57 & 16.08 \\
\hline Oats & 10.00 & 10.00 & 15.00 & - & - & 15.00 \\
\hline Corn & 17.00 & 11.58 & 16.69 & 1.65 & 8.51 & 16.25 \\
\hline Triticale & 0.40 & 0.43 & 0.40 & - & - & - \\
\hline Peas & 23.53 & 30.00 & 30.00 & 15.81 & 25.35 & 30.00 \\
\hline Potato protein & 5.00 & - & - & 5.00 & - & - \\
\hline Broad beans & 1.00 & 1.00 & 6.94 & - & - & - \\
\hline Lupine & - & - & 2.87 & - & - & 3.32 \\
\hline Rapeseed press cake & 13.45 & 8.46 & 5.31 & 6.89 & 10.61 & 0.13 \\
\hline Soybean press cake & - & 10.55 & 2.77 & - & 3.31 & 1.36 \\
\hline Sunflower press cake & - & - & 12.05 & - & - & 10.27 \\
\hline Sainfoin & - & - & 5.00 & - & - & 5.01 \\
\hline $\mathrm{MCP}$ & 0.53 & 0.52 & 0.48 & 0.40 & 0.34 & 0.37 \\
\hline Lime & 0.78 & 0.79 & 0.82 & 0.65 & 0.71 & 0.63 \\
\hline Sodium chloride & 0.08 & 0.08 & 0.07 & 0.00 & - & - \\
\hline Vitamin-mineral mix & 1.60 & 1.60 & 1.60 & 1.60 & 1.60 & 1.60 \\
\hline \multicolumn{7}{|c|}{ Analysed nutrient content (expressed per kg feed) } \\
\hline Dry matter, g & 892 & 891 & 896 & 896 & 891 & 891 \\
\hline Ash, g & 58 & 60 & 64 & 51 & 54 & 54 \\
\hline Crude fibre, $g$ & 50 & 50 & 80 & 42 & 49 & 80 \\
\hline Crude fat, $\mathrm{g}$ & 39 & 37 & 43 & 29 & 32 & 38 \\
\hline Crude protein, $g$ & 184 & 185 & 185 & 158 & 156 & 156 \\
\hline Digestible energy, MJ & 13.4 & 13.4 & 12.8 & 13.4 & 13.4 & 12.8 \\
\hline \multicolumn{7}{|c|}{ Digestible essential amino acids ${ }^{1}$} \\
\hline Lysine, \% & 0.86 & 0.86 & 0.80 & 0.65 & 0.65 & 0.63 \\
\hline Methionine, $\%$ & 0.27 & 0.26 & 0.24 & 0.23 & 0.23 & 0.21 \\
\hline Cystine, \% & 0.26 & 0.21 & 0.22 & 0.23 & 0.19 & 0.18 \\
\hline Threonine, $\%$ & 0.55 & 0.50 & 0.48 & 0.46 & 0.41 & 0.39 \\
\hline Tryptophan, \% & 0.15 & 0.15 & 0.14 & 0.14 & 0.12 & 0.12 \\
\hline Phenylalanine, \% & 0.72 & 0.69 & 0.64 & 0.66 & 0.56 & 0.55 \\
\hline Tyrosine, $\%$ & 0.53 & 0.47 & 0.44 & 0.46 & 0.37 & 0.37 \\
\hline Valine, $\%$ & 0.71 & 0.65 & 0.63 & 0.62 & 0.53 & 0.53 \\
\hline Leucine, $\%$ & 1.17 & 1.09 & 1.04 & 0.98 & 0.87 & 0.87 \\
\hline Isoleucine, $\%$ & 0.59 & 0.57 & 0.55 & 0.49 & 0.44 & 0.45 \\
\hline Histidine, $\%$ & 0.34 & 0.36 & 0.34 & 0.27 & 0.29 & 0.28 \\
\hline \multicolumn{7}{|c|}{ Fatty acids, $\%$ of total fatty acids } \\
\hline SFA & 29.31 & 30.42 & 27.02 & 28.63 & 26.82 & 27.05 \\
\hline MUFA & 30.84 & 26.43 & 26.94 & 22.62 & 27.87 & 23.53 \\
\hline PUFA & 39.85 & 43.14 & 46.04 & 48.75 & 45.31 & 49.42 \\
\hline $\mathrm{PUI}^{2}, \mathrm{~g}$ & 3.79 & 2.89 & 4.00 & 2.10 & 3.10 & 3.10 \\
\hline $\mathrm{IVI}^{3}, \mathrm{~g}$ & 4.62 & 3.02 & 4.96 & 2.18 & 3.93 & 3.60 \\
\hline
\end{tabular}

${ }^{1}$ The content of digestible essential amino acids and the content of saturated (SFA), monounsaturated (MUFA) and polyunsaturated (PUFA) fatty acids were based on nutritional characteristics of ingredients estimated from their chemical analyses with Allix

${ }^{2}$ PUI (PUFA index): $-0.300 \times \mathrm{SFA}+0.457 \times$ MUFA $+0.119 \times$ PUFA (fatty acid contents are expressed as $\mathrm{g} / \mathrm{kg}$ of feed)

${ }^{3}$ IVI (iodine value index): $-0.743 \times \mathrm{SFA}+0.829 \times \mathrm{MUFA}+0.212 \times \mathrm{PUFA}$ (fatty acid contents are expressed as $\mathrm{g} / \mathrm{kg}$ of feed) 
access to their specific diet and to drinking water. The feeding system recorded all daily visits at the feeder, feed intake (FI) per visit and time spent at the feeder. Data evaluations considered only feeder visits that coincided with the intake of feed (but not sham visits). Between-visit intervals shorter than $5 \mathrm{~min}$ (which was used as the meal criterion) were regarded as within meal feeder visits (WMFV) and these visits were grouped into meals (De Haer and Merks 1992). As proposed by Carcò et al. (2018), the day, rather than the single meal, was considered the temporal basis for describing the feeding behaviour of the pigs in the experimental period. The total FI, total feeder visits and total feeding time per day per pig were therefore calculated. Those data were then used to calculate the average total time spent feeding per day (TTF expressed in min), the average frequency of feeder visits $(\mathrm{FFV})$, the average time per visit $(\mathrm{TV}=\mathrm{TTF} / \mathrm{FFV}$, expressed in min), the average daily feed intake (ADFI), the mean feed intake per visit (FIV $=\mathrm{ADFI} / \mathrm{FFV}$, expressed in $\mathrm{g}$ ), the mean rate of feed intake (RFI = $\mathrm{ADFI} / \mathrm{TTF}$ expressed in $\mathrm{g} / \mathrm{min}$ ) and the interval between two meals (FI expressed in min).

Each pig's body weight (BW) was determined weekly. The pigs were switched from the grower to the finisher diet when the BW on the day of weighing was greater than $60 \mathrm{~kg}$. Pigs were slaughtered when BW was $>105 \mathrm{~kg}$ at the research abattoir of Agroscope, after being fasted for approximately $12 \mathrm{~h}$. Prior to slaughter, the live BW was determined. A detailed description of the slaughter procedure was previously provided by Bee et al. (2016). Briefly, 30 min after exsanguination, the weights of hot carcasses were assessed. At the 10th rib level, the backfat from each right carcass side was excised, freed from the skin and muscle, vacuum packed in opaque bags and stored at $-20{ }^{\circ} \mathrm{C}$ until analysis. Subsequently, the carcasses were chilled at $2{ }^{\circ} \mathrm{C}$ for $24 \mathrm{~h}$. At one day postmortem, the left-side cold carcass weight was determined and subsequently scanned using dual-energy X-ray absorptiometry (Lunar iDXA, GE HealthCare, Opfikon, Switzerland). Carcass yield was determined as the proportion of the hot carcass weight over the BW at slaughter. The water, ash, protein, fat and energy contents of the carcass were calculated using the iDXA values and the regressions published by Kasper et al. (2020).

\section{Characteristics of the adipose tissue}

The dry matter, total fat and fatty acid contents of the adipose tissue were measured by near-infrared spectroscopy (NIR) using a Fourier transform (FT) NIR instrument (NIRFlex N-500; Büchi Labortechnik AG, Flawil, Switzerland) operated in the diffuse reflectance mode. The fat tissue was thawed and then thoroughly mixed to form a soft paste. Two aliquots per sample were scanned at ambient temperature in a glass measuring cell with a diameter of $3.4 \times 2.5 \mathrm{~cm}$ and placing a metallic accessory on the surface to ensure homogeneous pressure on the sample. Three average spectra were taken, each with an average of 32 raw spectra, between 1000 and $2500 \mathrm{~nm}$ (10000 and 4000 $\mathrm{cm}^{-1}$ ), with a resolution of $8 \mathrm{~cm}^{-1}$. The NIR prediction models were based on reference data for fatty acid methyl esters, determined as previously described (Ampuero Kragten et al. 2014). The iodine value (IV) was calculated as the amount of iodine that would react with the total sum of double bonds of the fatty acid methyl esters. The NIR prediction models were based on $\sim 1500$ spectra in the calibration set and $\sim 600$ spectra in the validation set (different samples for calibration and validation sets). The prediction models were developed with the NIRCal® software (Büchi Labortechnik AG) using Partial Least Squares algorithms with various mathematical pretreatments, including nle (normalisation to unit length), db1 (1st derivative BCAP 5 points), dg2 (second derivative Savistky Golay 9 points) and snv (standard normal variate). The root mean squared error of prediction values for DM, the sum of n-3 fatty acids, the sum of n- 6 fatty acids (all in $\mathrm{g} / \mathrm{kg}$ ), SFA, MUFA, PUFA (all as $\%$ of total fatty acids), total fat (as \% of sample mass) and IV were 11.70, 1.9, 4.8, 0.43, 0.55, $0.42,21.30$ and 0.48 , respectively. The NIR prediction models were based on reference data sets with the following value ranges: DM: 736.6 to $944.9 \mathrm{~g} / \mathrm{kg}$; total fat: 66 to $99 \%$; sum of n-6 fatty acids: 31.2 to 178.9 $\mathrm{g} / \mathrm{kg}$; sum of n-3 fatty acids: 6.2 to $53.9 \mathrm{~g} / \mathrm{kg}$; SFA: 30.3 to $45.4 \%$; MUFA: 40.5 to $54.9 \%$; PUFA: 6.6 to $25.6 \%$; IV: 54.4 to 85.4 . The coefficient of determination $\left(R^{2}\right)$ and the standard error of prediction (SEP) ranged from 0.92 to 0.97 and from 0.2 to $0.6 \%$ ( $2 \%$ for total fat), respectively.

\section{Calculations and statistical analysis}

The nutrient and energy content of the carcasses at the start of the experiment were estimated using the BW and the protein and energy content of carcasses from female and castrated pigs weighing approximately $20 \mathrm{~kg}$ (RuizAscacibar et al. 2019). These values, together with those 
obtained from the iDXA measurements at slaughter, were used to determine the nutrient and energy accretion rate. The data for protein and energy accretion and the protein and digestible energy intake were combined to calculate the protein and energy deposition efficiency in the carcasses.

The data were analysed with the PROC MIXED of SAS, with the feeding treatments, the sex and the oneway interaction as fixed effects and litters as random effects. No relevant feeding treatment $\times$ sex interactions were observed. Therefore, the least square mean for the fixed effect of feeding treatment and for sex were presented. Multiple mean comparisons for the feeding treatment were performed with the PDIFF option and the Tukey adjustment. The effects were considered significant at $P<0.05$.

\section{Results}

Diets

By design, the T100-CF diets had on average a 3.4\% unit greater crude fibre content and, consequently, a lower content of digestible energy (Table 1). The crude protein content was similar among the grower and finisher diets of the three dietary treatments. However, when expressed on a per $g$ digestible lysine basis, the levels of digestible methionine, threonine, tryptophan (only in the finisher diets), phenylalanine, tyrosine, valine and isoleucine were lower than in the T95 diet, ranging from -15.5 to $-2.0 \%$ units in both the T100 and the T100-CF diets. The imbalance was, on average, greater in the finisher $(-7.6 \%)$ than in the grower ($3.4 \%)$ diets and greater in the $\mathrm{T} 100(-6.5 \%)$ than in the T100-CF $(-4.6 \%)$ treatment.

\section{Growth performance}

To reach the target slaughter weight of equal or greater than $105 \mathrm{~kg} \mathrm{BW}$, the T100-CF pigs stayed, on average, 4.6 days longer $(P<0.05)$ on feed than did the T95 and T100 pigs (Table 2). Although ADFI did not differ between treatments in the grower and finisher period, the ADG was lower $(P<0.05)$ in the T100-CF group pigs during the grower phase. The overall feed conversion ratio was greater $(P<0.05)$ in T100-CF than T95 and T100 pigs, and this difference was greater in the grower than in the finisher period. Because the diets were not isocaloric, the energy conversion ratio, expressed as DE intake per gain, was also calculated. The data showed that the overall energy conversion ratio was greater $(P<0.05)$ in the T100-CF than in the T95 treatment, with intermediate values in the T100 group. These differences were primarily observed in the grower period. The average PUI and IVI (expressed in $\mathrm{g} / \mathrm{kg}$ ingested feed) was lowest in the T95 and greatest in the T100-CF group, with intermediate values in the T100 group $(P<0.01)$.

Regardless of the dietary treatment, females stayed longer $(P<0.05)$ on feed, ingested less $(P<0.05)$ feed, had less $(P<0.05) \mathrm{DE}$ and grew slower $(P<0.05)$. This was true for the grower as well as the finisher period. However, female pigs were markedly more $(P<0.05)$ feed and energy efficient than the castrates.

\section{Feeding behaviour}

The monitored feeding behaviour traits suggested a consistent difference between the T95 versus the T100 and T100-CF pigs regarding how the feed was ingested (Table 3). In the grower period, the total time eating (TTF) did not differ between treatment groups; however, the T95 pigs went fewer $(P<0.05)$ times to the feeder (FFV), stayed for a longer time (TV) $(P<$ $0.05)$; ingested more $(P<0.05)$ feed per visit (FIV) and had a longer $(P<0.05)$ in-between-meal interval (FI) when compared with the T100 and T100-CF pigs. The number of feeder visits within a meal (WMFV) was greater $(P<0.05)$ in T100-CF and T100 than in T95 pigs. In contrast to the grower period, the TTF in the finisher period was longer $(P<0.05)$ in T100-CF than in T100 pigs, with intermediate values for the T95 pigs. Nevertheless, as seen for the grower period, in the finisher period, theT95 pigs went fewer $(P<0.05)$ times to the feeder (FFV), stayed for a longer $(P<0.05$; TV), ingested more $(P<0.05)$ feed per visit (FIV) and had a longer time $(P<0.05)$ in-between-meal interval $(\mathrm{FI})$ than T100 and T100-CF pigs. Similar to the grower period, the T100-CF pigs visited the feeder more times within a meal $(P<0.05$; WMFV) compared to the T95 and T100 pigs.

The T100 pigs spent less time eating in total (dTTF) $(P<0.05)$ and per visit $(\mathrm{dTV})(P<0.05)$ and visited the feeder fewer (dFFV; $P<0.05)$ times compared to the T95 and T100-CF pigs in the finisher period than in the grower period. From the grower to the finisher period, feed intake per visit (dFIV) increased to a greater extent 
Table 2 Growth performance of female and castrated pigs fed three different grower and finisher diets

\begin{tabular}{|c|c|c|c|c|c|c|c|c|c|}
\hline \multirow[t]{2}{*}{ Item $^{3}$} & \multicolumn{3}{|c|}{ Treatment $^{1}$} & \multicolumn{2}{|l|}{ Sex } & \multirow[t]{2}{*}{ SEM } & \multicolumn{3}{|c|}{$P$ value ${ }^{2}$} \\
\hline & T95 & $\mathrm{T} 100$ & T100-CF & Female & Castrate & & $\mathrm{T}$ & $\mathrm{S}$ & $\mathrm{T} \times \mathrm{S}$ \\
\hline \multicolumn{10}{|l|}{ BW, kg } \\
\hline Start of the grower period & 22.6 & 22.4 & 22.2 & 22.4 & 22.4 & 0.54 & 0.75 & 0.90 & 0.76 \\
\hline Start of the finisher period & 64.3 & 64.2 & 63.1 & 63.3 & 64.5 & 0.74 & 0.21 & 0.04 & 0.69 \\
\hline Slaughter & 109.7 & 110.1 & 109.1 & 110.2 & 109.1 & 1.08 & 0.65 & 0.20 & 0.31 \\
\hline \multicolumn{10}{|l|}{ ADG, kg/day } \\
\hline Grower & $0.861^{\mathrm{b}}$ & $0.847^{\mathrm{b}}$ & $0.765^{\mathrm{a}}$ & 0.801 & 0.847 & 0.0171 & $<0.01$ & $<0.01$ & 0.26 \\
\hline Finisher & 1.082 & 1.108 & 1.107 & 1.079 & 1.119 & 0.0297 & 0.56 & 0.09 & 0.38 \\
\hline Overall & $0.964^{\mathrm{b}}$ & $0.965^{\mathrm{b}}$ & $0.913^{\mathrm{a}}$ & 0.928 & 0.966 & 0.0196 & $<0.01$ & 0.02 & 0.95 \\
\hline \multicolumn{10}{|l|}{ Total FI, kg } \\
\hline Grower & $86.29^{\mathrm{a}}$ & $90.82^{\mathrm{ab}}$ & $96.69^{\mathrm{b}}$ & 87.36 & 95.18 & 2.765 & $<0.01$ & $<0.01$ & 0.79 \\
\hline Finisher & 128.70 & 128.34 & 133.96 & 129.58 & 131.09 & 3.656 & 0.24 & 0.61 & 0.65 \\
\hline Overall & $215.09^{\mathrm{a}}$ & $219.27^{\mathrm{a}}$ & $230.76^{\mathrm{b}}$ & 217.09 & 226.32 & 4.220 & $<0.01$ & $<0.01$ & $<0.01$ \\
\hline \multicolumn{10}{|l|}{ ADFI, kg/day } \\
\hline Grower & 1.783 & 1.839 & 1.809 & 1.712 & 1.909 & 0.0494 & 0.39 & $<0.01$ & 0.19 \\
\hline Finisher & 3.076 & 3.111 & 3.232 & 2.986 & 3.294 & 0.0824 & 0.08 & $<0.01$ & 0.86 \\
\hline Overall & 2.382 & 2.416 & 2.428 & 2.297 & 2.520 & 0.0583 & 0.59 & $<0.01$ & 0.45 \\
\hline \multicolumn{10}{|l|}{ Daily DE intake, MJ/day } \\
\hline Grower & $23.89^{\mathrm{ab}}$ & $24.63^{\mathrm{b}}$ & $23.15^{\mathrm{a}}$ & 22.59 & 25.19 & 0.650 & 0.03 & $<0.01$ & 0.17 \\
\hline Finisher & 40.61 & 41.06 & 41.37 & 39.00 & 43.03 & 1.084 & 0.71 & $<0.01$ & 0.83 \\
\hline Overall & 31.63 & 32.09 & 31.08 & 30.12 & 33.07 & 0.765 & 0.26 & $<0.01$ & 0.42 \\
\hline \multicolumn{10}{|l|}{ Feed conversion ratio, $\mathrm{kg} / \mathrm{kg}$} \\
\hline Grower & $2.067^{\mathrm{a}}$ & $2.169^{\mathrm{b}}$ & $2.364^{\mathrm{c}}$ & 2.141 & 2.260 & 0.0450 & $<0.01$ & $<0.01$ & 0.85 \\
\hline Finisher & $2.844^{\mathrm{ab}}$ & $2.812^{\mathrm{a}}$ & $2.922^{\mathrm{b}}$ & 2.767 & 2.952 & 0.0526 & 0.03 & $<0.01$ & 0.06 \\
\hline Overall & $2.470^{\mathrm{a}}$ & $2.503^{\mathrm{a}}$ & $2.659^{\mathrm{b}}$ & 2.475 & 2.614 & 0.0407 & $<0.01$ & $<0.01$ & 0.20 \\
\hline \multicolumn{10}{|l|}{$\mathrm{DE}$ intake/ADG, MJ/kg } \\
\hline Grower & $27.70^{\mathrm{b}}$ & $29.07^{\mathrm{a}}$ & $30.26^{\mathrm{a}}$ & 28.22 & 29.77 & 0.592 & $<0.01$ & $<0.01$ & 0.83 \\
\hline Finisher & 37.54 & 37.12 & 37.41 & 36.14 & 38.57 & 0.689 & 0.71 & $<0.01$ & 0.06 \\
\hline Overall & $32.81^{\mathrm{a}}$ & $33.25^{\mathrm{ab}}$ & $34.03^{\mathrm{b}}$ & 32.45 & 34.28 & 0.537 & 0.01 & $<0.01$ & 0.18 \\
\hline Average PUI, $\mathrm{g} / \mathrm{kg}$ ingested feed & $2.78^{\mathrm{a}}$ & $3.01^{\mathrm{b}}$ & $3.48^{\mathrm{c}}$ & 3.08 & 3.10 & 0.012 & 0.01 & 0.16 & 0.39 \\
\hline Average IVI, $\mathrm{g} / \mathrm{kg}$ ingested feed & $3.16^{\mathrm{a}}$ & $3.55^{\mathrm{b}}$ & $4.17^{\mathrm{c}}$ & 3.62 & 3.64 & 0.018 & 0.01 & 0.27 & 0.26 \\
\hline \multicolumn{10}{|l|}{ Days on feed, day } \\
\hline Grower & $48.6^{\mathrm{a}}$ & $49.5^{\mathrm{a}}$ & $53.8^{\mathrm{b}}$ & 51.3 & 49.9 & 1.44 & $<0.01$ & 0.23 & 0.38 \\
\hline Finisher & 42.1 & 41.7 & 41.7 & 43.9 & 39.8 & 1.45 & 0.94 & $<0.01$ & 0.94 \\
\hline Overall & $90.7^{\mathrm{a}}$ & $91.1^{\mathrm{ab}}$ & $95.5^{\mathrm{b}}$ & 95.0 & 89.8 & 1.98 & 0.02 & $<0.01$ & 0.62 \\
\hline Age at slaughter, day & 162.2 & 162.2 & 166.1 & 164.7 & 162.2 & 2.86 & 0.23 & 0.25 & 0.88 \\
\hline
\end{tabular}

\footnotetext{
${ }^{1} 95 \%, 95 \%$ of organic feed ingredients; $100 \%, 100 \%$ organic feed ingredients; $100 \%-\mathrm{CF}, 100 \%$ organic feed ingredients plus increased crude fibre content

${ }^{2} P$ values of the main factors experimental treatment $(\mathrm{T})$, sex $(\mathrm{S})$ and the $\mathrm{T} \times \mathrm{S}$ interaction

${ }^{3} B W$, body weight; grower, 22.4-63.9 kg BW; finisher, 63.9-109.6 kg BW; overall, 22.4-109.6 kg BW; $A D G$, average daily gain; FI, feed intake; $A D F I$, average feed intake; $D E$, digestible energy; PUI and IVI, calculated as the sum of the PUI/IVI of the grower diet $\times$ feed intake in the grower period and PUI/IVI of the finisher diet $\times$ feed intake in the finisher period divided by the total feed intake.

${ }^{a b c}$ Least square means within treatment with different superscript differ $(P<0.05)$
} 
Table 3 Feeding behaviour in the grower and finisher period of female and castrated pigs fed three different grower and finisher diets

\begin{tabular}{|c|c|c|c|c|c|c|c|c|c|}
\hline \multirow[t]{2}{*}{ Item $^{3}$} & \multicolumn{3}{|c|}{ Treatment $^{1}$} & \multicolumn{2}{|l|}{ Sex } & \multirow[t]{2}{*}{ SEM } & \multicolumn{3}{|c|}{$P$ value ${ }^{2}$} \\
\hline & T95 & $\mathrm{T} 100$ & T100-CF & Female & Castrate & & $\mathrm{T}$ & $\mathrm{S}$ & $\mathrm{T} \times \mathrm{S}$ \\
\hline \multicolumn{10}{|l|}{ Grower period } \\
\hline $\mathrm{TTF}, \mathrm{min}$ & 62.9 & 65.4 & 70.1 & 64.3 & 68.0 & 3.62 & 0.15 & 0.21 & 0.90 \\
\hline $\mathrm{FFV}, n$ & $9.9^{\mathrm{a}}$ & $13.2^{\mathrm{b}}$ & $12.2^{\mathrm{b}}$ & 11.9 & 11.6 & 1.01 & $<0.01$ & 0.70 & 0.32 \\
\hline WMFV, $n$ & $11.7^{\mathrm{a}}$ & $17.7^{\mathrm{b}}$ & $16.0^{\mathrm{b}}$ & 15.3 & 14.9 & 1.84 & $<0.01$ & 0.76 & 0.50 \\
\hline $\mathrm{TV}, \min ^{4}$ & $6.7^{\mathrm{b}}$ & $5.2^{\mathrm{a}}$ & $6.0^{\mathrm{ab}}$ & 5.7 & 6.3 & 0.53 & $<0.01$ & 0.10 & 0.04 \\
\hline FIV, $g^{5}$ & $193^{\mathrm{b}}$ & $149^{\mathrm{a}}$ & $156^{\mathrm{a}}$ & 153 & 178 & 16.3 & $<0.01$ & 0.05 & 0.04 \\
\hline RFI, $g / \min$ & 29 & 29 & 27 & 27 & 29 & 1.63 & 0.25 & 0.20 & 0.90 \\
\hline FI, min & $76.2^{\mathrm{b}}$ & $56.7^{\mathrm{a}}$ & $62.2^{\mathrm{a}}$ & 62.5 & 67.6 & 6.18 & $<0.01$ & 0.24 & 0.08 \\
\hline \multicolumn{10}{|c|}{ Finisher period ${ }^{6}$} \\
\hline $\mathrm{TTF}, \min$ & $64.3^{\mathrm{ab}}$ & $58.7^{\mathrm{a}}$ & $69.0^{\mathrm{b}}$ & 60.0 & 67.9 & 3.97 & 0.03 & 0.01 & 0.73 \\
\hline $\mathrm{FFV}, n$ & $6.2^{\mathrm{a}}$ & $8.5^{\mathrm{b}}$ & $8.8^{\mathrm{b}}$ & 8.2 & 7.5 & 0.95 & $<0.01$ & 0.28 & 0.95 \\
\hline WMFV, $n$ & $7.0^{\mathrm{a}}$ & $10.6^{\mathrm{a}}$ & $25.5^{\mathrm{b}}$ & 15.1 & 13.6 & 2.74 & $<0.01$ & 0.50 & 0.95 \\
\hline $\mathrm{TV}, \min$ & $11.5^{\mathrm{b}}$ & $7.7^{\mathrm{a}}$ & $8.3^{\mathrm{a}}$ & 8.1 & 10.3 & 1.22 & $<0.01$ & $<0.01$ & 0.15 \\
\hline FIV, $\mathrm{g}$ & $547^{\mathrm{b}}$ & $416^{\mathrm{a}}$ & $395^{\mathrm{a}}$ & 405 & 501 & 55.4 & $<0.01$ & 0.02 & 0.29 \\
\hline RFI, g/min & 49 & 54 & 48 & 51 & 50 & 3.0 & 0.17 & 0.74 & 0.87 \\
\hline $\mathrm{FI}, \min$ & $99.9^{\mathrm{b}}$ & $81.5^{\mathrm{a}}$ & $75.0^{\mathrm{a}}$ & 78.3 & 92.6 & 9.62 & 0.01 & 0.05 & 0.35 \\
\hline \multicolumn{10}{|c|}{ Difference between the grower and finisher period } \\
\hline dTTF, min & $1.4^{\mathrm{a}}$ & $-6.7^{\mathrm{b}}$ & $-1.1^{\mathrm{a}}$ & -4.6 & 0.2 & 2.58 & $<0.01$ & 0.04 & 0.27 \\
\hline $\mathrm{dFFV}, n$ & $-3.7^{\mathrm{ab}}$ & $-4.7^{\mathrm{b}}$ & $-3.3^{\mathrm{a}}$ & -3.7 & -4.1 & 0.47 & 0.02 & 0.22 & 0.06 \\
\hline dWMFV, $n$ & $-4.7^{\mathrm{a}}$ & $-7.1^{\mathrm{a}}$ & $9.4^{\mathrm{b}}$ & -0.4 & 9.4 & 2.33 & $<0.01$ & 0.65 & 0.75 \\
\hline $\mathrm{dTV}, \min$ & $4.8^{\mathrm{c}}$ & $2.6^{\mathrm{b}}$ & $2.4^{\mathrm{a}}$ & 2.4 & 4.1 & 0.84 & $<0.01$ & $<0.01$ & 0.42 \\
\hline dFIV, g & $354^{\mathrm{b}}$ & $267^{\mathrm{ab}}$ & $240^{\mathrm{a}}$ & 251 & 323 & 43.1 & 0.01 & 0.03 & 0.63 \\
\hline dRFI, g/min & 21 & 25 & 22 & 24 & 22 & 1.8 & 0.06 & 0.12 & 0.49 \\
\hline $\mathrm{dFI}, \min$ & 23.6 & 24.7 & 12.7 & 15.6 & 25.1 & 5.23 & 0.05 & 0.03 & 0.50 \\
\hline
\end{tabular}

${ }^{1} 95 \%, 95 \%$ of organic feed ingredients; $100 \%, 100 \%$ organic feed ingredients; $100 \%$-CF, $100 \%$ organic feed ingredients plus increased crude fibre content

${ }^{2} P$ values of the main factors experimental treatment $(\mathrm{T})$, sex $(\mathrm{S})$ and the $\mathrm{T} \times \mathrm{S}$ interaction

${ }^{3} T T F$, total time feeding per day; $F F V$, frequency of feeder visits; $W M F V$, within meal feeder visits; $T V$, time per visit; $F I V$, feed intake per visit; RFI, rate of feed intake; $F I$, interval between two meals

${ }^{4} \mathrm{TV}$ of castrated pigs fed the $95 \%$ diet was longer $(P<0.05)$ then of pigs fed the $100 \%$ or $100 \%$-CF diets $(8.9$ vs 5.5 or 6.6 min)

${ }^{5}$ FIV of castrated pigs fed the $95 \%$ diet was greater $(P<0.05)$ than of pigs fed the Bio100\%/100\%-CF $(282$ vs 171 or $177 \mathrm{~g})$

${ }^{6} d T T F$, difference between TTF in the grower and finisher period; $d F F V$, difference between FFV in the grower and finisher period; $W M F V$, difference between WMFV in the grower and finisher period; $T V$, difference between TV in the grower and finisher period; FIV, difference between FIV in the grower and finisher period; RFI, difference between RFI in the grower and finisher period; FI, difference between FI in the grower and finisher period

${ }^{\mathrm{abc}}$ Least square means within treatment with different superscript differ $(P<0.05)$

in T95 than in T100-CF pigs, with intermediate values for T100 pigs.

In the grower period, the feeding behaviour was similar between the sexes except for a lower $(P=0.05)$ FIV, which coincided with the lower average daily feed intake in females. By contrast, in the finisher period, females spent less $(P=0.01)$ time eating in total and per visit and they ingested, on average, $100 \mathrm{~g}$ less $(P=0.02)$ feed per visit. The feeding behaviour of females and castrates changed differently from the grower to the finisher period. The daily total feeding time (dTTF), feeding time per visit (dTV) and the time interval between meals (dFI) became shorter $(P \leq 0.04)$, but the feed intake per visit (dFIV) was smaller $(P=0.01)$ in females than in castrates. 
Carcass nutrient content, accretion and nutrient deposition efficiency

At the start and the end of the experiment, the carcass nutrient and energy content did not differ between treatments (Table 4). However, the average daily carcass gain was lower $(P<0.01)$ in the T100-CF than in the T95 and T100 pigs. This gain difference was due to differences $(P$ $\leq 0.02)$ in water, protein and fat, but not in ash accretion.
The protein and energy deposition efficiency was lower $(P \leq 0.01)$ in the T100-CF than in the T95 and T100 pigs.

At slaughter, the carcasses of female pigs contained more $(P \leq 0.03)$ water, ash and protein and less $(P<$ 0.01 ) fat and gross energy than did the carcasses of the castrates. Regardless of these differences, the lower $(P<$ $0.01)$ daily carcass gain was exclusively due to lower $(P$ $<0.05)$ daily fat deposition and, ultimately, lower $(P<$ $0.05)$ energy deposition. Protein deposition efficiency

Table 4 Carcass nutrient content, nutrient accretion rate and nutrient deposition efficiency of female and castrated pigs fed three different grower and finisher diets

\begin{tabular}{|c|c|c|c|c|c|c|c|c|c|}
\hline \multirow[t]{2}{*}{ Item } & \multicolumn{3}{|c|}{ Treatment $^{1}$} & \multicolumn{2}{|l|}{ Sex } & \multirow[t]{2}{*}{ SEM } & \multicolumn{3}{|c|}{$P$ value $^{2}$} \\
\hline & T95 & $\mathrm{T} 100$ & T100-CF & Female & Castrate & & $\mathrm{T}$ & $\mathrm{S}$ & $\mathrm{T} \times \mathrm{S}$ \\
\hline \multicolumn{10}{|c|}{ Carcass nutrient composition } \\
\hline \multicolumn{10}{|c|}{ At the start of the experiment } \\
\hline Carcass, $\mathrm{g}$ & 17,328 & 17,203 & 17,086 & 17,199 & 17,212 & 434.6 & 0.84 & 0.97 & 0.73 \\
\hline Water, g & 12,219 & 12,131 & 12,049 & 12,128 & 12,137 & 306.5 & 0.84 & 0.97 & 0.73 \\
\hline Ash, g & 670 & 335 & 661 & 665 & 665 & 16.8 & 0.84 & 0.97 & 0.73 \\
\hline Protein, $g$ & 2717 & 1698 & 2679 & 2697 & 2699 & 68.2 & 0.84 & 0.97 & 0.73 \\
\hline Fat, $g$ & 1722 & 1710 & 1698 & 1709 & 1711 & 43.2 & 0.84 & 0.97 & 0.73 \\
\hline Gross energy, MJ & 130 & 129 & 129 & 129 & 129 & 3.3 & 0.84 & 0.97 & 0.73 \\
\hline \multicolumn{10}{|l|}{ At slaughter } \\
\hline Carcass, $\mathrm{g}$ & 86,545 & 87,595 & 85,571 & 86,786 & 86,354 & 1134.4 & 0.15 & 0.60 & 0.91 \\
\hline Water, g & 48,983 & 49,186 & 48,669 & 49,950 & 47,941 & 911.2 & 0.72 & $<0.01$ & 0.75 \\
\hline Ash, g & 3067 & 3102 & 3109 & 3141 & 3044 & 66.0 & 0.70 & 0.03 & 0.50 \\
\hline Protein, $g$ & 14,823 & 14,885 & 14,723 & 15,133 & 14,488 & 291.4 & 0.73 & $<0.01$ & 0.74 \\
\hline Fat, $g$ & 19,717 & 20,467 & 19,080 & 18,582 & 20,927 & 829.7 & 0.14 & $<0.01$ & 0.48 \\
\hline Gross energy, MJ & 1125 & 1156 & 1097 & 1087 & 1166 & 30.4 & 0.10 & $<0.01$ & 0.54 \\
\hline \multicolumn{10}{|l|}{ Daily gain } \\
\hline Carcass & $774^{\mathrm{b}}$ & $783^{b}$ & $723^{a}$ & 742 & 778 & 16.6 & $<0.01$ & $<0.01$ & 0.79 \\
\hline Water, g/day & $411^{b}$ & $411^{\mathrm{b}}$ & $386^{\mathrm{a}}$ & 403 & 402 & 11.1 & 0.02 & 0.88 & 0.99 \\
\hline Ash, g/day & 27 & 27 & 26 & 27 & 27 & 0.8 & 0.18 & 0.66 & 0.73 \\
\hline Protein, g/day & $135^{\mathrm{b}}$ & $135^{\mathrm{b}}$ & $127^{\mathrm{a}}$ & 133 & 132 & 3.7 & 0.02 & 0.93 & 0.99 \\
\hline Fat, g/day & $202^{\mathrm{ab}}$ & $209^{\mathrm{b}}$ & $185^{\mathrm{a}}$ & 181 & 216 & 10.1 & $<0.01$ & $<0.01$ & 0.30 \\
\hline Gross energy, MJ & $11.2^{\mathrm{b}}$ & $11.4^{\mathrm{b}}$ & $10.3^{\mathrm{a}}$ & 10.3 & 11.6 & 0.39 & $<0.01$ & $<0.01$ & 0.33 \\
\hline \multicolumn{10}{|c|}{ Nutrient deposition efficiency ${ }^{3}, \%$} \\
\hline Protein & $37.58^{\mathrm{b}}$ & $37.25^{\mathrm{b}}$ & $34.72^{\mathrm{a}}$ & 38.31 & 34.72 & 1.195 & 0.01 & $<0.01$ & 0.43 \\
\hline Energy & $38.83^{\mathrm{b}}$ & $39.57^{\mathrm{b}}$ & $36.64^{\mathrm{a}}$ & 37.68 & 39.02 & 0.704 & $<0.01$ & 0.01 & 0.45 \\
\hline
\end{tabular}

${ }^{1} 95 \%, 95 \%$ of organic feed ingredients; $100 \%, 100 \%$ organic feed ingredients; $100 \%-\mathrm{CF}, 100 \%$ organic feed ingredients plus increased crude fibre content

${ }^{2} P$ values of the main factors experimental treatment $(\mathrm{T})$, sex $(\mathrm{S})$, and the $\mathrm{T} \times \mathrm{S}$ interaction

${ }^{3}$ Protein deposition efficiency, carcass protein content at slaughter - protein content at $20 \mathrm{~kg}$ BW/total protein intake; energy deposition efficiency, gross energy content of the carcass at slaughter - gross energy content of the carcass at $20 \mathrm{~kg} \mathrm{BW} / \mathrm{total} \mathrm{DE}$ intake

${ }^{\mathrm{ab}}$ Least square means within treatment with different superscript differ $(P<0.05)$ 
was greater $(P<0.01)$ and energy deposition efficiency was lower $(P=0.01)$ in females than in castrates.

Adipose tissue characteristics

The dietary treatments had no impact on the dry matter and fat content of the adipose tissue (Table 5). However, the adipose tissue of T100-CF pigs contained less $(P<$ $0.05)$ SFA and more $(\mathrm{P}<0.05)$ MUFA and consequently had a greater IV than the adipose tissue of the T95 and T100 pigs. The sum of $n-6$ fatty acids was greatest $(P<$ $0.05)$ in the adipose tissue of T100-CF and least in T95 pigs, with intermediate values for T100 pigs.

Irrespective of the dietary treatments, the dry matter and fat content were lower $(P \leq 0.05)$ in the adipose tissue of females than of castrates. The lower fat content coincided with greater $(P<0.01)$ amounts of n-6 and n3 fatty acids and PUFA, a higher $(\mathrm{P}<0.01)$ IV and a lower $(\mathrm{P}<0.01)$ SFA level in females.

\section{Discussion}

Growth performance and feeding behaviour

Dietary energy and protein concentration and EAA balance are key drivers of the voluntary feed intake, and therefore daily gain, in pigs ( $\mathrm{Li}$ and Patience 2017). Beaulieu et al. (2009) showed that a lowering of the dietary available energy content caused pigs to attempt to maintain a constant daily energy intake by eating more feed. However, this ability to compensate for lower energy density is not always observed (Wu et al. 2007), especially when the maximum feed intake is limited by the ingestion capacity of the pig (Black et al. 1986). This appears to be the case for the T100-CF pigs, as they did not increase their feed intake to compensate for the $0.6 \mathrm{MJ} / \mathrm{kg}$ lower DE density of the grower and finisher diets. This lack of a response could be related to the bulking effect (on average $+3.4 \%$ greater crude fibre content) caused by the lupine, the sunflower press cake and the sainfoin.

Evidence for a limitation of DE intake by the greater crude fibre content can be found in the feeding behaviour results. The T100-CF pigs went more often to the feeder but stayed for a shorter time. The rate of feed intake was therefore not greater, so the amount of ingested feed was comparable to that of the T95 pigs. The shorter time spent at the feeder could suggest that the physical feed intake capacity was reached earlier (Ratanpaul et al. 2019). In addition to the difference in DE content, the T100 and T100-CF diets also had a lower and imbalanced EAA content when expressed per gram lysine. This deficiency was intentional for two reasons. First, the EAA deficiency should be minimal

Table 5 Fatty acid composition of adipose tissue of female and castrated pigs fed three different grower and finisher diets

\begin{tabular}{|c|c|c|c|c|c|c|c|c|c|}
\hline \multirow[t]{2}{*}{ Item $^{3}$} & \multicolumn{3}{|c|}{ Treatment $^{1}$} & \multicolumn{2}{|l|}{ Sex } & \multirow[t]{2}{*}{ SEM } & \multicolumn{3}{|c|}{$P$ value $^{2}$} \\
\hline & T95 & $\mathrm{T} 100$ & T100-CF & Female & Castrates & & $\mathrm{T}$ & $\mathrm{S}$ & $\mathrm{T} \times \mathrm{S}$ \\
\hline Dry matter, $\%$ & 89.29 & 90.15 & 89.28 & 88.58 & 90.57 & 0.677 & 0.25 & $<0.01$ & 0.18 \\
\hline Fat, \% & 88.01 & 88.80 & 87.43 & 87.17 & 88.99 & 1.307 & 0.45 & 0.05 & 0.19 \\
\hline Iodine value & $66.8^{\mathrm{a}}$ & $67.2^{\mathrm{a}}$ & $70.1^{\mathrm{b}}$ & 69.55 & 66.52 & 1.364 & $<0.01$ & $<0.01$ & 0.66 \\
\hline \multicolumn{10}{|c|}{ Expressed as $\%$ of total fatty acids } \\
\hline SFA & $37.69^{\mathrm{b}}$ & $37.75^{\mathrm{b}}$ & $34.99^{\mathrm{a}}$ & 35.95 & 37.67 & 0.926 & $<0.01$ & $<0.01$ & 0.86 \\
\hline MUFA & $47.89^{\mathrm{a}}$ & $47.37^{\mathrm{a}}$ & $49.44^{\mathrm{b}}$ & 48.29 & 48.18 & 0.474 & $<0.01$ & 0.69 & 0.35 \\
\hline PUFA & 14.04 & 14.50 & 15.12 & 15.34 & 13.76 & 0.602 & 0.12 & $<0.01$ & 0.35 \\
\hline n-6 & $11.19^{\mathrm{a}}$ & $11.63^{\mathrm{ab}}$ & $12.26^{\mathrm{b}}$ & 12.35 & 11.04 & 0.496 & 0.05 & $<0.01$ & 0.45 \\
\hline$n-3$ & 1.20 & 1.24 & 1.16 & 1.32 & 1.08 & 0.094 & 0.60 & $<0.01$ & 0.99 \\
\hline
\end{tabular}

\footnotetext{
${ }^{1} 95 \%, 95 \%$ of organic feed ingredients; $100 \%, 100 \%$ organic feed ingredients; $100 \%$-CF, $100 \%$ organic feed ingredients plus increased crude fibre content

${ }^{2} P$ values of the main factors experimental treatment $(\mathrm{T})$, sex $(\mathrm{S})$ and the $\mathrm{T} \times \mathrm{S}$ interaction

${ }^{3}$ SFA, saturated fatty acids; MUFA, monounsaturated fatty acids; PUFA, polyunsaturated fatty acids; n-6, sum of n-6 fatty acids; n-3, sum of n-3 fatty acids

${ }^{\mathrm{ab}}$ Least square means within treatment with different superscript $\operatorname{differ}(P<0.05)$
} 
to ensure as low as possible an impact on growth. Second, the T100 and T100-CF diets had to concur with the $100 \%$ organic feed rule but without imposing an excessive increase in the dietary crude protein content.

We succeeded in formulating isonitrogenous grower and finisher diets; however, by substituting potato protein with grain legumes, the EAA to DE or EAA to lysine ratios were lower in the T100 and T100-CF than in the T95 diets. For instance, compared to the T95 diet, the tyrosine, valine and leucine levels were lower, on average, by $8 \%$ points in the grower and by $14 \%$ points in the T100 finisher diet. Nevertheless, neither feed intake nor growth performance was impaired in the T100 compared to the T95 group. This contrasts with the results of Ruiz-Ascacibar et al. (2017), who reported no changes in the feed intake when protein and EAA restricted diets $(-20 \%)$ were fed, but the severe restriction impaired growth from 21 to $102 \mathrm{~kg} \mathrm{BW}$. SuárezBelloch et al. (2015) and Schiavon et al. (2018) observed lower feed intake and growth rate in the BW range of 86 to $130 \mathrm{~kg}$ at a low EAA supply or with an imbalanced EAA profile. Compared to these studies, the T95, T100 and T100-CF grower and finisher diets had markedly greater crude protein contents, and the EAA deficiencies and imbalances were smaller; this might explain the lack of any effect on feed intake and growth. Surprisingly, the T95 and T100 pigs ingested the same amount of feed, but at different paces. Both the T100$\mathrm{CF}$ and T100 pigs spent less time eating per visit, ingested less feed per visit and took longer breaks between meals when compared with the T95 pigs. To compensate for their shorter and smaller meals, the T100-CF and T100 pigs went more often to the feeder.

As previously mentioned, with respect to the nutrient content, the major difference between the T100 and T95 diets was the greater imbalance of branched-chain amino acids. As pointed out by Li and Patience (2017), imbalances in branched-chain amino acids are rapidly detected by the pig and can affect the feed intake. Recently, Tian et al. (2019) showed that branched-chain amino acid levels are involved in intestinal nutrient sensing through regulation of the amino acid type- 1 taste receptors $1 / 3$ in the intestine or through activation of the general control nonderepressible 2 kinase and eukaryotic initiation factor $2 \alpha$ in the hypothalamus. The other difference between the T95 and T100 diets is the feed ingredients used to formulate the diets. The T100 grower and finisher diet had greater amounts of peas and soybean press cake. Whether these differences affected the preferences for the diets and consequently the feeding behaviour is difficult to evaluate as the experiment was not set up as a feed preference study (Solà-Oriol et al. 2011).

Regardless of the dietary treatments, an interesting observation was that, despite the approximately $70 \%$ greater daily feed intake in the finisher than in the grower period, the pigs spent marginally more total time (T95: $+1.4 \mathrm{~min})$ or even less total time (T100: -6.7 min; T100-CF: $-1.1 \mathrm{~min}$ ) at the feeder and visited the feeders, on average, four times less. To compensate, the pigs stayed on average 1.5 times longer per visit and ingested 2.6 times more feed, while eating 1.81 times more feed per minute. On the one hand, the greater meal size coincided with the increasing capacity of the digestive tract with increasing body weight, while, on the other hand, the longer interval between meals could have reflected a longer lasting satiety.

Marked differences were noted in feed intake and, ultimately, in growth between the females and castrates despite ad libitum feed access. Ruiz-Ascacibar et al. (2017) observed similar differences in feed intake between the two sexes under the same experimental conditions. Those authors hypothesised that the cause of the reduced feed intake might be the dominance of castrates over the females when sharing group pens equipped with single-space feeders. The feeding behaviour data confirmed this hypothesis, as the females displayed shorter feeder visits and smaller feed intakes per visit when compared with the castrates. This difference was more evident in the finisher than in the grower period and reinforced the fact that dominance issues became more evident with increasing BW.

Compared to the grower phase, females spent, on average, 4.6 min less time in ingesting the greater amount of feed, whereas the castrates spent a similar amount (+ $0.1 \mathrm{~min}$ ) of time at the feeder and their number of feeder visits was $34 \%$ lower, on average. To compensate, the castrated pigs stayed 1.5 times as long and ingested 2.6 times more feed per visit, whereas the rate of feed intake increased at a similar rate in females (1.9-fold) and in castrates (1.7-fold). The greater meal size per visit for the castrates might explain the greater between-meal intervals in the finisher than in the grower period.

\section{Carcass nutrient and energy content and deposition efficiency}

With respect to the dietary treatments, two main findings can be drawn from the data on carcass nutrient and 
energy content at slaughter and the nutrient intake. The first is that the daily accretion of carcass mass, carcass protein, carcass fat and carcass gross energy, as well as protein and fat deposition efficiency, was lower in the T100-CF than in the T95 and T100 pigs. This finding can be explained by the fact that, to reach the target slaughter weight, the T100-CF pigs had to stay 4.6 days longer on feed, on average during which $\mathrm{T} 100-\mathrm{CF}$ pigs ingested $6 \%$ more feed, in total. Similarly, the longer experimental period can explain the lower energy deposition rate, as the average daily DE intake was similar among all three treatments (expressed in $\mathrm{MJ} /$ day for T95: 32.0; T100: 32.4; T100-CF: 31.4; SEM: 0.78; $P$ $=0.26$ ). The second finding is that the deposition rates and deposition efficiency did not differ between T100 and T95 pigs, despite the lower EAA content of the T100 grower and finisher diets. Other authors reported impaired growth and postulated that pigs fed low EAA diets use the amino acids more efficiently, resulting in improved protein deposition efficiency (Millet et al. 2011; Ruiz-Ascacibar et al. 2017). In the present study, the reduction was limited to particular EAAs like the $\alpha$ amino acids and phenylalanine and was less severe than in the previous studies. In addition, the lower EAA supply had no effect on the overall growth performance.

Differences in chemical body composition between female and castrated pigs are well documented (NRC 2012). Similar to the results reported by Ruiz-Ascacibar et al. (2017), the protein deposition rate in the present study was similar for both sexes, whereas the most extensive fat deposition-and, consequently, the greatest energy deposition rates-were observed in the castrated pigs. In agreement with the results of several previous studies (Rodriguez-Sanchez et al. 2011; RuizAscacibar et al. 2019), the castrates use their greater feed intake primarily for deposition of backfat and not for lean tissue deposition, whereas females use the ingested food more efficiently for protein deposition.

\section{Backfat composition}

For more than three decades, Swiss commercial abattoirs have used both the slaughter weight and the meat content of the carcass as payment criteria; however, the IV (also called the fat score) and, more recently, the PUFA level of the backfat is now also included for quality control. When the PUFA or IV values of the backfat surpass $15.5 \%$ or 70 , respectively, the pig producers are penalised (Scheeder and
Muller 2014). Recognising that the PUFA level and the IV in the backfat are highly correlated with the dietary fatty acid composition, Stoll (2016) developed the PUI and IVI feeding recommendations that take into account the maximum sum of SFA, MUFA and PUFA levels in a grower-finisher diet necessary to ensure a PUFA level and IV in the backfat below the established thresholds.

In the present study, the PUI and IVI of the grower and finisher diets differed between the treatment groups. Furthermore, within the treatment group, the PUI and IVI of the grower diet differed from those of the finisher diet. Nevertheless, the PUI and IVI restrictions were fulfilled, as the values were always below $5.1 \mathrm{~g} / \mathrm{kg}$ for PUI and $7.8 \mathrm{~g} / \mathrm{kg}$ for IVI (Stoll 2016). Taking into account the ingested amount of grower and finisher diet, the average PUI and IVI increased in the order of T95 > T100 > T100-CF. In accordance, these differences were observed in the PUFA level and the IV of the backfat. Except for the IV in the backfat of T100-CF pigs, the defined threshold PUFA levels and IV were not exceeded. The IV in the T100-CF group was 0.1 unit over the expected limit due to the greater unsaturation level caused by a greater amount of MUFA and a lower amount of SFA in the backfat of the T100-CF compared to T100 and T95 pigs. Surprisingly, despite being below the required PUI and IVI thresholds, four T95, two T100 and five T100-CF pigs had levels of PUFA and/or IV values greater than $15.5 \%$ and 70 , respectively. For these animals, the PUFA values ranged from 15.6 to $20.0 \%$ and the IVI values ranged from 70.1 to 79.6 .

The MUFA level, with oleic acid being the most abundant fatty acid, is determined by the dietary supply as well as by the elongation and desaturation of saturated homologues like palmitic and stearic acid. Dietary PUFAs of the n-6 family are known to impair the activity of stearoyl-CoA-desaturase, the key enzyme in the desaturation process of stearic acid (Bee et al. 2002; Kouba and Mourot 1998). Thus, in the present experiment, the $\sum \mathrm{n}-6$ fatty acid level in the backfat was greater in the T100-CF group due to the greater PUFA intake, although a lower MUFA and greater SFA level would be expected in the T100-CF than in the T95 and T100 groups. However, pigs of the T100-RF group ingested considerable amounts of sunflower cake, a source rich in oleic acid. The greater incorporation of oleic acid due to the elevated dietary supply therefore might have downregulated the stearoyl-CoAdesaturase. 


\section{Conclusion}

The results of this study support the conclusion that a slight reduction in the dietary EAA level, when complying with the $100 \%$ organic feeding regulation (T100), had no negative effect on the growth performance, carcass composition or nutrient deposition efficiency of production pigs. By contrast, elevation of the crude fibre content and a slight reduction in the dietary EAA impaired the daily growth, total feed intake, feed efficiency and carcass nutrient deposition efficiency and altered the pig feeding behaviour. The imposed EAA deficiency had no impact on the pig production traits, and the effects observed in the T100-CF group were attributable primarily to the greater crude fibre and lower DE content of the diet. The PUI and IV feeding recommendations appeared to be equally applicable for $100 \%$ organic diets, although a risk of exceeding the threshold may exist when the inclusion of oil-rich press cakes or roughages raises the crude fibre content above that found in common grower-finisher diets.

Acknowledgements The authors are grateful to the Swiss Department of Agriculture for funding the research project "Bioschwein 100.0".

Funding Open Access funding provided by Agroscope.

Open Access This article is licensed under a Creative Commons Attribution 4.0 International License, which permits use, sharing, adaptation, distribution and reproduction in any medium or format, as long as you give appropriate credit to the original author(s) and the source, provide a link to the Creative Commons licence, and indicate if changes were made. The images or other third party material in this article are included in the article's Creative Commons licence, unless indicated otherwise in a credit line to the material. If material is not included in the article's Creative Commons licence and your intended use is not permitted by statutory regulation or exceeds the permitted use, you will need to obtain permission directly from the copyright holder. To view a copy of this licence, visit http://creativecommons.org/licenses/by/4.0/.

\section{References}

Agroscope (2017) Fütterungsempfehlungen und Nährwerttabellen für Schweine. 3rd edn Lehrmittel Zentrale, Zollikofen, Switzerland

Ampuero Kragten S, Collomb M, Dubois S, Stoll P (2014) Zusammensetzung von Fettsäuren in der Tierfütterung Analysenmethoden Agrarforschung Schweiz

Beaulieu AD, Williams NH, Patience JF (2009) Response to dietary digestible energy concentration in growing pigs fed cereal grain-based diets. J Anim Sci 87:965-976. https://doi. org/10.2527/jas.2007-0834

Bee G, Gebert S, Messikommer R (2002) Effect of dietary energy supply and fat source on the fatty acid pattern of adipose and lean tissues and lipogenesis in the pig. J Anim Sci 80:1564-1574

Bee $G$ et al (2016) Hydrolysable tannin-based diet rich in gallotannins has a minimal impact on pig performance but significantly reduces salivary and bulbourethral gland size Animal 11:1617-1625. https://doi.org/10.1017 /S1751731116002597

Black J, Campbell R, Williams I, James K, Davies G (1986) Simulation of energy and amino acid utilisation in the pig. Res Dev Agr 3:121-145

Bracher A (2019) Körnerleguminosen als alternative Proteinquellen $\mathrm{zu}$ importierten Eiweissträgern Agrarforschung Schweiz 10:180-189

Carcò G, Gallo L, Dalla Bona M, Latorre MA, Fondevila M, Schiavon S (2018) The influence of feeding behaviour on growth performance, carcass and meat characteristics of growing pigs PLOS ONE 13:e0205572. https://doi. org/10.1371/journal.pone.0205572

De Haer L, Merks J (1992) Patterns of daily food intake in growing pigs. Anim Sci 54:95-104

Hadorn R, Eberhard P, Guggisberg D, Piccinali P, SchlichtherleCerny H (2008) Effect of fat score on the quality of various meat products. Meat Sci 80:765-770. https://doi.org/10.1016 /j.meatsci.2008.03.020

Hansen LL, Claudi-Magnussen C, Jensen SK, Andersen HJ (2006) Effect of organic pig production systems on performance and meat quality. Meat Sci 74:605-615

Holinger M, Früh B, Stoll P, Kreuzer M, Hillmann E (2018) Grass silage for growing-finishing pigs in addition to straw bedding: Effects on behaviour and gastric health. Livest Sci 218: 50-57. https://doi.org/10.1016/j.livsci.2018.10.012

Kasper C, Schlegel P, Ruiz-Ascacibar I, Stoll P, Bee G (2020) Correspondance of body composition and N, RA, P, Ca content obtained by chemical analyses and dual-energy $\mathrm{X}$ ray absorptiometry (DXA) in pigs Animal

Kouba M, Mourot J (1998) Effect of a high linoleic acid diet on D9-desaturase activity, lipogenesis and lipid composition of pig subcutaneous adipose tissue. Reprod Nutr Dev 38:31-37

Li Q, Patience JF (2017) Factors involved in the regulation of feed and energy intake of pigs. Anim Feed Sci Technol 233:2233. https://doi.org/10.1016/j.anifeedsci.2016.01.001

Millet S, Langendries K, Aluwé M, De Brabander DL (2011) Effect of amino acid level in the pig diet during growing and early finishing on growth response during the late finishing phase of lean meat type gilts. J Sci Food Agric 91: $1254-1258$

NRC (2012) Nutrient requirements of swine vol 11th revised edition, vol 11th revised edition. National Academy Press, Washington, DC, USA

Ratanpaul V, Williams BA, Black JL, Gidley MJ (2019) Review: Effects of fibre, grain starch digestion rate and the ileal brake on voluntary feed intake in pigs Animal 13:2745-2754. https://doi.org/10.1017/S1751731119001459

Rodriguez-Sanchez JA, Sanz MA, Blanco M, Serrano MP, Joy M, Latorre MA (2011) The influence of dietary lysine restriction during the finishing period on growth performance and carcass, meat, and fat characteristics of barrows and gilts 
intended for dry-cured ham production. J Anim Sci 89:36513662. https://doi.org/10.2527/jas.2010-3791

Ruiz-Ascacibar I, Stoll P, Bee G, Schlegel P (2019) Dynamics of the mineral composition and deposition rates in the empty body of entire males, castrates and female pigs Animal 13: 950-958. https://doi.org/10.1017/S1751731118002495

Ruiz-Ascacibar I, Stoll P, Kreuzer M, Boillat V, Spring P, Bee G (2017) Impact of amino acid and CP restriction from 20 to $140 \mathrm{~kg} \mathrm{BW}$ on performance and dynamics in empty body protein and lipid deposition of entire male, castrated and female pigs Animal 11:394-404. https://doi.org/10.1017 /S1751731116001634

Scheeder MRL, Muller M (2014) Nachhaltige Sicherung der Fettqualität bei Mastschweinen.

Schiavon S, Dalla Bona M, Carcò G, Carraro L, Bunger L, Gallo L (2018) Effects of feed allowance and indispensable amino acid reduction on feed intake, growth performance and carcass characteristics of growing pigs PLOS ONE 13: e0195645 doi:https://doi.org/10.1371/journal.pone.0195645

Solà-Oriol D, Roura E, Torrallardona D (2011) Feed preference in pigs: effect of selected protein, fat, and fiber sources at different inclusion rates1 J Anim Sci 89:3219-3227. https://doi.org/10.2527/jas.2011-3885

Stoll P Fütterungsempfehlung Fettqualität beim Schwein. In: Agrarwissenschaften If (ed) ETH-Schriftenreihe zur Tierernährung, ETH-Zurich, 2016. Umdenken in der Eiweissversorgung der Nutztiere. pp 200-202
Suárez-Belloch J, Guada J, Latorre M (2015) Effects of sex and dietary lysine on performances and serum and meat traits in finisher pigs. Animal 9:1731-1739

Sundrum A, Aragon A, Schulze-Langenhorst C, Buetfering L, Henning M, Stalljohann G (2011) Effects of feeding strategies, genotypes, sex, and birth weight on carcass and meat quality traits under organic pig production conditions $\mathrm{Njas}-$ Wageningen. J Life Sci 58:163-172. https://doi.org/10.1016 /j.njas.2011.09.006

Tian M, Heng J., Song H., Shi K., Lin X., Chen F., Guan W., Zhang S. (2019) Dietary branched-chain amino acids regulate food intake partly through intestinal and hypothalamic amino acid receptors in piglets J Agric Food Chem 67:68096818 doi:https://doi.org/10.1021/acs.jafc.9b02381

Wlcek S, Zollitsch W (2004) Sustainable pig nutrition in organic farming: by-products from food processing as a feed resource. Renew Agric Food Syst 19:159-167

Wu Z, Li D, Ma Y, Yu Y, Noblet J (2007) Evaluation of energy systems in determining the energy cost of gain of growingfinishing pigs fed diets containing different levels of dietary fat. Arch Anim Nutr 61:1-9. https://doi.org/10.1080 /17450390601106614

Zollitsch W (2007) Challenges in the nutrition of organic pigs. J Sci Food Agric 87:2747-2750

Publisher's note Springer Nature remains neutral with regard to jurisdictional claims in published maps and institutional affiliations. 